Серія: Педагогічні науки. - Вип.3. - Бердянськ : БДПУ, 2019. - 453 с.

УДК 378.24:331.103.255] : [005.336.2:004.9]

DOI 10.31494/2412-9208-2019-1-3-256-265

\title{
DEVELOPMENT OF STUDENTS' DIGITAL COMPETENCE IN THE PROCESS OF CARRYING OUT RESEARCH WORK
}

\author{
РОЗВИТОК ЦИФРОВОЇ КОМПЕТЕНТНОСТІ \\ СТУДЕНТІВ У ПРОЦЕСІ ЗДІЙСНЕННЯ НАУКОВО- \\ ДОСЛІДНОї РОБОТИ
}

\author{
Liudmyla DYBKOVA, \\ Doctor of Pedagogical Sciences, \\ Associate Professor \\ Kyiv National Economic University \\ named after Vadym Hetman \\ 54/1 Prospect Peremogy \\ 03057 Kyiv Ukraine
}

https://orcid.org/0000-0002-3920-118X

dybkova.kneu@ukr.net

\author{
Людмила ДИБКОВА, \\ доктор педагогічних наук, доцент
}

Original manuscript received: October 01, 2019

Київський національний економічний університет імені Вадима Гетьмана $\triangle 03057$, Україна, Київ,

Revised manuscript accepted: December 11, 2019

\begin{abstract}
Nowadays the dramatic rise and convergence of emerging new information technology causes rapidly and radically transforming in all spheres of society's life, including the educational environment. The purpose of the research presented in this article was to explore how the digitization of the economy impacting on the transformation of learning process and on approaches to organization students' scientific research. New mobile and Internet technologies lead to emergence of new jobs based on the use of technologies such as artificial intelligence, virtual and augmented reality, biotechnology, Internet of things, cloud computing. Therefore, equipping students with the digital literacy skills necessary to be productive in a rapidly changing work environment is a key task of modern education. The basic tasks of student research work and organizational measures for presentation of the results of the completed work are analyzed. It is emphasized that the widespread use of new technologies in the implementation of research by students increases the level of their digital competence. Author's tasks are presented, including mastering of work with online services, creation of interactive charts and diagrams for presentation of research results, development of interactive presentations in various software environments, creation of own sites and videos, conducting surveys in a network environment, etc. Such tasks are aimed at developing critical thinking, creativity and the ability to use digital resources effectively; the ability to evaluate the reliability and significance of information received from different sources; understanding the basics of security in endless digital space; improving the level of communication in cooperation with others; deepening understanding of the importance and ability to learn continuously.
\end{abstract} research.

Key words: labor market, digital technologies, digital competence, student 
Постановка проблеми. Нові Інтернет і мобільні технології змінюють економічний та суспільний простір кожної країни, стають рушійною силою в зміні суті базової інфрраструктури профресійної діяльності, сприяють виникненню нових і модифрікації наявних професій, розширюють сфери здійснення наукових досліджень та розвитку особистості кожного громадянина. I така тенденція незворотна.

Науково-дослідна робота (НДР) студентів $€$ невід'ємною та важливою частиною освітнього процесу. Особливо актуальною вона стає в умовах постійного й стрімкого оновлення інформаційного фрахово-орієнтованого масиву, коли рівень професійної компетентності фахівця залежить від його здатності самостійно набувати нові знання, вміння й навички та швидко адаптувати їх до сучасних технологій, які постійно розвиваються та вдосконалюються. Передбачається, що руйнівні зміни в бізнес-моделях матимуть значні наслідки для стану зайнятості в найближчі роки. Очікується, що багато із основних фракторів трансформації, які зараз впливають на глобальні галузі, позначаться на робочих місцях, починаючи від створення значної кількості нових робочих місць до заміщення їх загалом, а також від підвищення продуктивності праці до розширення прогалин у кваліфікації. У такому ландшафтті зайнятості, який швидко змінюється, здатність прогнозувати та готуватися до майбутніх вимог до навичок, змісту робочих місць та сукупного впливу на зайнятість стає все більш важливою для бізнесу, урядів та окремих людей, щоб повністю використати можливості, представлені цими тенденціями - і пом'якшити небажані результати (World Economic Forum, 2016: 3).

Отже, через технології, що стрімко змінюються, сучасний освітній процес має бути зорієнтований на підготовку такого спеціаліста, який, окрім базової професійної підготовки, має й розвинені особистісні компетентності (високий рівень аналітичного та критичного мислення, здатність до постійного саморозвитку та творчості, вміння ефективно спілкуватися та вирішувати конфліктні ситуації тощо, а також, що особливо важливо, має високий рівень цифрової компетентності. I НДР студентів стає вагомим чинником, що значно підвищує професійну підготовку майбутнього фрахівця в умовах цифрровізації економічного й суспільного простору.

Аналіз останніх досліджень. Проблемам розвитку нових інтернет та мобільних технологій та аналізу їх впливу на ринок праці, вимоги до цифрової компетентності майбутніх фрахівців присвячені дискусії на Світовому Економічному форумі та доповідях $€ C$, дослідження науковців S. Kluzer, L. Pujol Priego, B. Adams, M. Cummins, K. Schwab та багатьох інших. Дидактичні можливості хмарних технологій та цифрових ресурсів в освітньому процесі досліджували у своїх роботах В. Биков, Ю. Богачков, К. Бугайчук, В. Кухаренко, В. Лапінський, О. Спірін, М. Шишкіна та ін. Аналізу змісту, фрормам та методам організації науково-дослідної роботи у ЗВО присвячені роботи О. Глазунової, С. Гончарова, О. Дубасенюка, О. Кузьмінської, О. Повідайчик, О. Пометун, О. Сергеєвої та ін. Проблеми організації НДР студентів аналізували Г. Артемчук, М. Білуха, С. Важинський, В. Шейко, Ю. Сурмін, В. Яремчук та ін. 
Цифровізація економіки призводить до появи нових робочих місць, які базуються на використанні таких технологій, як штучний інтелект, віртуальна та доповнена реальність, нанотехнології, Інтернет речей, блокчейн, хмарні обчислення та ін. Враховуючи прискорені темпи розвитку технологій, четверта промислова революція потребує приділення особливої уваги на здатність працівників до постійної адаптації й засвоєнню нових навичок і підходів у різноманітних контекстах (Schwab, 2016: 47). Зазначається, що 40\% європейських роботодавців мають труднощі в пошуку людей з необхідними навичками для зростання та інновацій (European Commission, 2016: 2). Порівняно 3 експоненційною швидкістю підключень і технологічних досягнень упровадження ефективного цифрового навчання, програм навчання та зміна освітньої політики відбувається набагато повільніше, і цей розрив у швидкості дедалі зростає [c.9, DQ Global Standards].

Отже, освітня система має підготувати сучасного фрахівця із широким спектром цифрових навичок, які сприяють особистісній реалізації та професійному розвитку. Серед них: уміння ефективно використовувати цифрові ресурси; здатність оцінювати достовірність і значимість одержуваної з різних джерел інформації; розуміння основ безпеки в безмежному цифровому просторі; критичне мислення, високий рівень комунікативності у співпраці з іншими; розуміння важливості й вміння неперервно навчатися та ін. Саме такі якості формуються в тому числі й при виконанні студентами наукових досліджень.

"Особлива увага при здійсненні студентами НДР приділяється залученню студентів до збору, аналізу та узагальнення кращого практичного досвіду, проведення соціологічних та експериментальних досліджень, підготовки доповідей тощо" (Пономарьова, 2010: 143). Т. Яковенко розглядає НДР як фрактор розвитку творчого потенціалу студентів у креативному навчальному середовищі (Яковенко, 2012: 168). Підготовка студентів до НДР в умовах вищого навчального закладу повинна відбуватися у вигляді системи, яка б передбачала: навчальнонаукову діяльність, студентські наукові дослідження, а також реалізацію форм, методів і педагогічних умов, спрямованих на фрормування в студентів мотивації до здійснення наукових досліджень з опорою на індивідуалізацію навчального процесу (Повідайчик, 2017: 217).

Таким чином, дослідження різних аспектів організації НДР студентів ЗВО здійснюється багатьма науковцями. Проте цифровізація економічного та суспільного життя вимагає внесення відповідних змін і в освітню систему, в тому числі й в організацію НДС студентів. Метою статті $\epsilon$ аналіз сучасних тенденцій на ринку праці та методи вдосконалення цифрової компетентності студентів при здійсненні ними науково-дослідної роботи.

Виклад основного матеріалу. Зазначається, що $89 \%$ домогосподарств в $€ С$ мають доступ до Інтернету, але частка людей, які ніколи не користувалися Інтернетом, все ще значна. Вона найвища серед дорослих віком 65-74 років (37\%), тоді як серед населення $16-24$ років - 
менше 1\% (Digital Economy and Society Index Report, 2019: 6). Найбільша кількість користувачів Інтернету - молоді люди віком 16-24 років $(97 \%)$ (Digital Economy and Society Index Report, 2019: 4).

Дослідження, проведене серед 1005 студентів університету США, виявило, що ноутбуки використовуються найчастіше (63\%) для занять у класі, виконання домашніх завдань та підготовки до іспитів, i $\epsilon$ найважливішим пристроєм для навчання. Також можна зазначити наявність у студентів різноманітних цифрових пристроїв, якими вони активно користуються (Digital Economy and Society Index Report, 2019: 8). Окрім того, $65 \%$ студентів уважають, що цифрові навчальні технології допомагають їм у навчанні (серед них 35\% зазначають, що вони "дуже корисні", 30\% “надзвичайно корисні”) (Digital Study Trends Survey, 2017: 20).

Таким чином, сучасні студенти є «цифровими мешканцями», які виросли в епоху сучасних цифрових технологій, 3D i 4D графріки, мобільних технологій, комп'ютерних ігор і з легкістю опановують роботу із різноманітними пристроями, такими як ноутбуки, смартфони, планшети та інші сучасні гаджети.

У наукових дослідженнях наявні певні розбіжності в термінології різних авторів. Названо «цифровою грамотністю» таку, яка виходить за рамки здобуття ізольованих технологічних навичок, сприяє поглибленому розумінню цифрового середовища, що забезпечує інтуїтивну адаптацію до нових умов та створенню контенту з іншими (Adams et al., 2017: 22). Цифрова грамотність включає кілька типів: технічну (взаємодія з пристроями, за допомогою яких працюють із мережними та мобільними технологіями), інформаційну (взаємодія з програмним забезпеченням, яке дозволяє працювати з контентом) і комунікаційну, яка являє собою розуміння того, що спілкування відбувається в мережевому співтоваристві.

Автори іншого дослідження використовують термін «цифрова компетентність» і характеризують її як ключову трансверсальну компетенцію, яка означає здатність використовувати цифрові технології критично, спільно та творчо (Kluzer et al., 2018: 8). Ми погоджуємося із суттю такого визначення, доповнивши його: цифрова компетентність - це здатність оцінювати достовірність і значимість одержуваної з різних джерел інформації за допомогою самостійно встановлених критеріїв, вміння вирішувати пошукові завдання, пов'язані 3 незнайомим або неоднозначним контекстом. Вважаємо, що цифрова компетентність стає важливою для успішного пошуку та отримання роботи, а також для створення та ведення бізнесу чи професійної діяльності. Вміння знаходити потрібну інформацію, здатність до аналітичного та критичного ставлення до неї, використання різноманітного програмного забезпечення сприяє постійному професійному розвитку.

Разом з тим, як запит на нові навички збільшується, вони також створюють нові можливості для освіти і навчання, в тому числі й при здійсненні студентами НДР. Наукові лабораторії і гуртки, студентські наукові товариства, дискусійні клуби, науково-практичні семінари - це науковий простір, де на міждисциплінарній основі студенти можуть 
здійснювати повноцінну наукову працю, знайти однодумців, з якими можна порадитися і поділитися результатами своїх досліджень, отримати консультації та поради. У такому середовищі формується здатність студента-дослідника до критичного аналізу інформаційних масивів; творчий підхід до сприйняття знань й практичне застосування їх для вирішення завдань та наукових проблем; вміння аргументувати свою позицію, дискутувати та сприймати іншу думку.

Основними задачами НДР студентів $є$ : а) розвиток творчого і аналітичного мислення, розширення наукового кругозору; б) прищеплення стійких навичок самостійної науково-дослідницької роботи; в) систематизація та розширення теоретичних знань дисциплін, що вивчаються; г) вироблення уміння застосовувати теоретичні знання і сучасні методи наукових досліджень у практичній діяльності; д) засвоєння студентами методики проведення наукового експерименту; е) формування критичного мислення, усвідомленого відношення до тих чи інших поглядів, ідей, концепцій; ж) розвиток дослідницьких навичок та цифрової компетентності тощо.

Таким чином, науково-дослідницька робота студентів - форма навчальної діяльності, яка здійснюється під керівництвом викладача й скерована на проведення досліджень у проблемних сферах, виконання аналітичних робіт, що сприяє більш ґрунтовному засвоєнню навчального матеріалу, розвитку пізнавальної самостійності, вдосконаленню навичок самоосвіти студентами, а також підвищенню рівня цифрової компетентності.

Хелен Валкінгтон, розглядаючи дослідницьку діяльність студентів, зазначає, що викладач, можливо, бажає зробити більший акцент на навичках мислення вищого рівня, щоб студенти підтримували свої ідеї та переконання доказами; висловлювали критичні судження про цінність інформації, аргументів або методів, досліджуючи, яким чином було зібрано та інтерпретовано дані іншою командою студентів і як вона оцінює обґрунтованість та достовірність своїх висновків; синтезували та організовували ідеї, інформацію чи досвід у нові, більш складні інтерпретації та взаємозв'язки; виконували роботу над проектами, які потребують інтеграції ідей із різноманітних джерел (Walkington, 2015: 13).

Результати та дискусії. Організаційними заходами для представлення результатів НДР $€$ внутрішньовузівські, міжвузівські, регіональні і республіканські наукові конференції, конкурси, олімпіади та ін. В умовах цифровізації освітнього простору формати та стилі для висвітлення здобутків проведеної роботи стають значно різноманітними, починаючи від неофіційного до формального та професійного. Це можуть бути блоги та журнали відео; подкасти; Інтернет-конференції; виставки та покази, веб-сторінки; сторінки в соціальних мережах. Такі формати наближені до молодіжної Інтернет-аудиторії й надихають більшу кількість студентів долучитися до досліджень.

Необхідно зазначити, що однією з найбільших перешкод для студентів, які беруть участь у наукових дослідженнях, $€$ їхня 
невпевненість у тому, що їх робота гідна широкого розповсюдження. Студенти частіше очікують, що результати їхньої роботи оцінюються викладачами. Вважаємо, що необхідно максимально заохочувати та розвивати навички студентів до публічної презентації результатів здійсненої НДР. У цьому контексті зазначено, що ролі педагогів змінюються на кураторів та фасилітаторів навчального досвіду, заохочуючи здобувачів освіти розвивати кращі дослідницькі навички та формулювати глибші запитання (Adams et al., 2017: 34).

Аналізуючи питання організації НДР студентів, О. Сергеєва зазначає, що за останні десятиліття відбулися концептуальні зміни в підходах до здійснення науково-дослідної роботи в університетах США (активне залучення студентів до проведення досліджень, зміни в програмах та вибіркових дисциплінах, залучення до позааудиторної науково-дослідної роботи). Важливим елементом науково-дослідної роботи студентів США є комерціалізація освіти, а студентські проєкти, пов'язані 3 науковими дослідженнями, $€$ пріоритетними в організації науково-дослідній роботі студентів. (Сергеєва, 2018).

Хочемо закцентувати увагу на такій важливій компоненті науководослідної діяльності студентів, як формування в них коректного з точки зору науковості висловлення своїх думок. Як правило, викладачі приділяють значну увагу оформленню робіт, їх змістовому наповненню та відповідності заявленій темі. Але теоретичної та практичної підготовки для формування якісного наукового стилю під час проведення досліджень у студентів, особливо першокурсників, недостатньо.

Основними ознаками наукового стилю є: ясність і предметність тлумачень; логічна послідовність викладення змісту навчальної теми; об'єктивний аналіз; точність і лаконічність висловлювань; аргументованість й переконливість тверджень; аналіз отриманих результатів; докладні й стислі висновки.

Ще однією важливою проблемою $є$ нерозуміння студентами значення авторських прав. Це стає особливо актуальним в епоху доступності великого обсягу інформаційних ресурсів мережі Інтернет. Студенти копіюють роботу інших й, змінивши лише прізвище, видають її за свої власні результати. Викладачеві необхідно цій проблемі приділяти значно більшу увагу. Аналогічно стверджує й автор дослідження: навчальні заклади зобов'язані розвивати цифррові навички студентів, забезпечуючи майстерність відповідального й відповідного використання технологій, включаючи етикет в режимі он-лайн та розуміння студентами цифрових прав й обов'язків в умовах змішаного й онлайн навчання та за його межами (Adams et al., 2017: 22). 3 метою уникнення проблем 3 плагіатом необхідно розробляти для студентів навчальні завдання аналітичного, творчого характеру.

Наведемо приклади деяких завдань НДС у контексті формування цифрової компетентності, які ми пропонуємо студентам: сервісу.

1. Охарактеризуйте та розробіть приклад використання онлайн- 
Серія: Педагогічні науки. - Вип.3. - Бердянськ : БДПУ, 2019. - 453 с.

Ми наводимо перелік безкоштовних сервісів, доступних у мережі Інтернет, для вибору, хоча й дозволяємо студентам обрати й інший. Серед таких онлайн-сервісів можна назвати:

Google Docs - найпопулярніші онлайнові сервісні програми для виконання роботи над текстовим документом, електронною таблицею, презентацією, формами. 3 такими фрайлами можна працювати як y on-line так i y off-line режимах. Студенти можуть виконувати завдання як індивідуально, так й у складі кількох або групи студентів. Така сервісна програма також дозволяє створювати форми для здійснення опитувань, при цьому результати опитування розраховуються автоматично і можуть бути представлені для аналізу у вигляді діаграм або таблиць MS Excel.

Prezi - сервісна програма для створення мультимедійних нелінійних презентаций. Весь зміст презентації вміщено на першому слайді, фрагменти якого розгортаються в процесі перегляду презентації.

Tripline - онлайнова сервісна програма, за допомогою якої $\epsilon$ можливість створити віртуальну екскурсію. Інформацію може бути подано як у часових інтервалах, так і на географічних картах.

Learning Apps - онлайнова сервісна програма для створення різноманітних інтерактивних вправ. Окрім можливості створити власну вправу, студенти можуть використовувати й інші, збережені в окремих папках, які упорядковані за певними ознаками.

Videnot - програма, яка дає змогу додавати до відеозапису текстових нотаток.

2. Проаналізуйте обрані за заданою темою статистичні дані (значні обсяги яких можна знайти у мережі Інтернет). Відтворіть такі дані через інтерактивні графріки, діаграми.

3. Створіть презентацію для представлення результатів Вашої науково-дослідної роботи, яка вміщує різноманітні інтерактивні елементи програмного додатку MS PowerPoint.

4. Використовуючи Google-фрорму, здійсніть опитування за обраною темою, проаналізуйте результати та надайте їх у формі презентації.

5.Створіть відео-файл із поясненням невеликого навчального питання.

6. Результати здійсненого дослідження розмістіть на YouTubeканалі (або блозі соціальної мережі).

7. Використовуючи програми Google-site, WorkPress або інші, створіть власний сайт, на якому помістить отримані результати Вашого дослідження.

8. Організуйте серед створеної групи Інтернет-користувачів обговорення результатів Вашої науково-дослідної діяльності. У якості звіту можна надати або певні висловлювання або копії екрану із обговореннями.

Виконання таких або аналогічних навчальних завдань сприяє формуванню студентів як дослідників, а також удосконалює їхню цифрову компетентність.

Висновки. За результатами проведеного дослідження можна зробити висновок, що завдяки цифровізації освітнього процесу 


\section{Наукові записки БДПУ (http://bdpu.org/pedagogy/ua/)}

можливості для здійснення студентами НДР значно розширюються. Використання нових Інтернет та мобільних технологій сприяє формуванню вміння ефективно використовувати цифрові ресурси; здатності оцінювати достовірність і значимість одержуваної з різних джерел інформації; розумінню основ безпеки у безмежному цифровому просторі; розвиває критичне мислення, удосконалює рівень комунікативності в співпраці з іншими; поглиблює розуміння важливості й вміння неперервно навчатися та ін.

\section{Література}

1. Сергеєва О. Науково-дослідна робота студентів як ключовий елемент вищої освіти в США / О. Сергеєва // Зб. наук. пр. «Педагогіка та психологія». Харків, 2018. - Вип. 60.

2. Повідайчик О. Основні підходи до науково-дослідницької роботи студентів / О. Повідайчик // Науковий вісник Ужгородського університету. Серія: «Педагогіка. Соціальна робота». - 2017. - Вип. 1 (40). - С. 216-218.

3. Пономарьова Г. Науково-дослідна робота студентів у ВНЗ як складова їх професійної підготовки / Г. Пономарьова // Наукові записки кафедри педагогіки. - Харків, 2010. - Вип. XXIV.

4. Яковенко Т. Науково-дослідна робота як фрактор розвитку творчого потенціалу студентів у навчальному середовищі інженерно-педагогічного ВНЗ / Т. Яковенко // Наука і освіта. - 2012. - № 8.

5. Kluzer S., Pujol Priego L. (2018). DigComp into Action - Get inspired, make it happen. S. Carretero, Y. Punie, R. Vuorikari, M. Cabrera, and O'Keefe, W. (Eds.). Publications Office of the European Union, Luxembourg. Retrieved from doi:10.2760/112945.

6. European Commission (2016). Communication from the Commission to the European Parliament, the Council, the European Economic and Social Committee and the Committee of the Regions. A New Skills Agenda for Europe. Working Together to Strengthen Human Capital, Employability and Competitiveness. Brussels, Retrieved from: http://ec.europa.eu/transparency/regdoc/rep/1/2016/EN/COM-2016-356-F1-ENMAIN-PART-1.PDF

7. Adams, B., Cummins M., Davis, A., Freeman, A., Hall Giesinger, C., and Ananthanarayanan, V. (2017). "NMC Horizon Report: 2017" Higher Education Edition. Austin, Texas: The New Media Consortium. Retrieved from https://www.sconul.ac.uk/sites/default/files/documents/2017-nmchorizon-report-he-EN.pdf.

8. Digital Economy and Society Index Report. (2019). Use of Internet Services. Retrieved from https://ec.europa.eu/digital-single-market/en/use-internet

9. DQ Global Standards Report. (2019). Common Framework for Digital Literacy, Skills and Readiness. Coalition for Digital Intelligence (DCl) platform created in association with the World Economic Forum, and formed by the OECD, IEEE, and DQ Institute. Retrieved from https://www.dqinstitute.org/dq-framework.

10. Digital Study Trends Survey. (2017). Publ. McGraw-Hill Education. Retrieved from https://s3.amazonaws.com/ecommerce-prod.mheducation.com/unitas/ highered/ explore/sites/study-trends/2017-digital-trends-survey-results.pdf.

11. World Economic Forum (2016). The Future of Jobs Employment, Skills and Workforce Strategy for the Fourth Industrial Revolution. Retrieved from http://www3. weforum.org/docs/WEF Future of Jobs.pdf.

12. Schwab, K. (2016). The Fourth Industrial Revolution. New York: Currency. Retrieved from https://luminariaz.files.wordpress.com/2017/11/the-fourth-industrialrevolution-2016-21.pdf

13. Walkington, H. Students as researchers: Supporting undergraduate research 
Серія: Педагогічні науки. - Вип.3. - Бердянськ : БДПУ, 2019. - 453 с.

in the disciplines in higher education (2015). The Higher Education Academy. Retrieved from https://www.heacademy.ac.uk/ system/files/resources/ Students\% 20as\%20researchers 1.pdf

\section{References}

1. Serheieva, O. (2018). Naukovo-doslidna robota studentiv yak kliuchovyi element vyshchoi osvity $v$ USA [Student research as a key element of higher education in the United States], Pedagogy and Psychology, Vyp. 60 [in Ukrainian].

2. Povidaichyk, O. (2017). Osnovni pidkhody do naukovo-doslidnytskoi roboty studentiv [Basic approaches to student research work], Naukovyi visnyk Uzhgorod University Scientific Bulletin. Series: "Pedagogy. Social work", Vyp. 1 (40), 216-218. [in Ukrainian].

3. Ponomarova, H. (2010). Naukovo-doslidna robota studentiv u VNZ yak skladova yikh profesiinoi pidhotovky [Research work of students at universities as a component of their professional training], Scientific notes of the Department of Pedagogy, Vyp. XXIV. [in Ukrainian].

4. Yakovenko, T. (2012). Naukovo-doslidna robota yak faktor rozvytku tvorchoho potentsialu studentiv $u$ navchalnomu seredovyshchi inzhenernopedahohichnoho VNZ [Research work as a factor of development of students' creative potential in educational environment of engineering-pedagogical university], Science and Education, 8. [in Ukrainian].

5. Kluzer S., Pujol Priego L. (2018). DigComp into Action - Get inspired, make it happen. S. Carretero, Y. Punie, R. Vuorikari, M. Cabrera, and O'Keefe, W. (Eds.). Publications Office of the European Union, Luxembourg. Retrieved from doi:10.2760/112945.

6. European Commission (2016). Communication from the Commission to the European Parliament, the Council, the European Economic and Social Committee and the Committee of the Regions. A New Skills Agenda for Europe. Working Together to Strengthen Human Capital, Employability and Competitiveness. Brussels, Retrieved from: http://ec.europa.eu/transparency/regdoc/rep/1/2016/EN/COM-2016-356-F1-EN-MAINPART-1.PDF

7. Adams, B., Cummins M., Davis, A., Freeman, A., Hall Giesinger, C., and Ananthanarayanan, V. (2017). "NMC Horizon Report: 2017" Higher Education Edition. Austin, Texas: The New Media Consortium. Retrieved from https://www.sconul.ac.uk/sites/default/files/documents/2017-nmchorizon-report-he-EN.pdf.

8. Digital Economy and Society Index Report. (2019). Use of Internet Services. Retrieved from https://ec.europa.eu/digital-single-market/en/use-internet

9. DQ Global Standards Report. (2019). Common Framework for Digital Literacy, Skills and Readiness. Coalition for Digital Intelligence (DCI) platform created in association with the World Economic Forum, and formed by the OECD, IEEE, and DQ Institute. Retrieved from https://www.dqinstitute.org/dq-framework.

10. Digital Study Trends Survey. (2017). Publ. McGraw-Hill Education.

11. Retrieved from https://s3.amazonaws.com/ecommerceprod.mheducation.com/unitas/highered/explore/sites/study-trends/2017-digital-trendssurvey-results.pdf.

12. World Economic Forum (2016). The Future of Jobs Employment, Skills and Workforce Strategy for the Fourth Industrial Revolution. Retrieved from http://www3. weforum.org/docs/WEF Future of Jobs.pdf.

13. Schwab, K. (2016). The Fourth Industrial Revolution. New York: Currency. Retrieved from https://luminariaz.files.wordpress.com/2017/11/the-fourth-industrialrevolution-2016-21.pdf

14. Walkington, H. Students as researchers: Supporting undergraduate research in the disciplines in higher education (2015). The Higher Education Academy. Retrieved from https://www.heacademy.ac.uk/system/ files/resources/Students\%20as\%20researchers 1.pdf 


\section{АНОТАЦІЯ}

Стрімкий розвиток та конвергенція нових інфоормаційних технологій спричиняє швидку та кардинальну трансфоормацію у всіх сферах життя суспільства, включаючи освітне середовище. Метою дослідження, представленого у статті, було проаналізувати, як цифровізація економіки впливає на трансформацію навчального процесу, в тому числі й на організацію науково-дослідної роботи студентів. Нові мобільні та Інтернет-технології призводять до появи нових робочих місць на основі використання таких технологій, як итучний інтелект, віртуальна реальність, біотехнології, Інтернет речей, хмарні обчислення. Тому фрормування високого рівня цифрової компетентності, необхідної для профресійної роботи в умовах, що швидко змінюються, $\epsilon$ ключовим завданням сучасної освіти. Проаналізовано основні задачі науково-дослідної роботи студентів та організаційні заходи для представлення результатів виконаної роботи. Наголошується, що широке використання нових технологій при здійсненні студентами досліджень підвищує й рівень їхньої цифррової компетентності. Представлено авторські завдання, серед яких засвоєння роботи із онлайн сервісами, створення інтерактивних графріків та діаграм для представлення результатів дослідження, розробка інтерактивних презентацій у різних програмних середовищах, створення власних сайтів та відео, проведення опитувань у мережному середовищі та ін. Виконання таких завдань спрямовані на розвиток критичного мислення, креативності, вміння ефективно використовувати иифрові ресурси; здатності оцінювати достовірність і значимість одержуваної з різних джерел інфоормації; розуміння основ безпеки у безмежному цифровому просторі; удосконалення рівня комунікативності у співпраці з іншими; поглиблення розуміння важливості й вміння неперервно навчатися.

Ключові слова: ринок праці, цифррові технології, цифрова компетентність, науково-дослідна робота студентів 